\title{
The Desert Grassland, PASt AND PRESENT
}

\author{
Robert R. Humphrey \\ Range Ecologist, College of Agriculture, \\ University of Arizona, Tucson
}

(Presented at Grassland Symposium, Western Division, A.A.A.S. meeting, Corvallis, Oregon, USA. June 18, 1952.)

Most of the grassland areas below about 4,000 feet in southwestern North America are commonly referred to as the desert grassland (Shantz and Zon 1924) or, more occasionally, as the desert plains (Weaver and Clements 1929). This association extends discontinuously from southwestern Texas, through southern New Mexico, into southeastern Arizona and south into Mexico.

\section{PRESENT VEGETATION}

Originally an area of open grassland or grassland with scattered shrubs (Figure 1), much of this area today supports a mixture of shrubs and grasses with shrubs dominant. In Arizona, mesquite (Prosopis juliflora [Sw.] DC.), burroweed (Aplopappus tenuisectus Greene), and snakeweed (Gutierrezia spp.), together with acacias (Acacia spp.) and a number of cacti are the principal shrubs. In eastern Arizona, across southern New Mexico and into Texas, mesquite, creosote bush (Larrea tridentata [DC.] Coville), Spanish bayonet (Yucca spp.), tarbush (Flourensia cernua DC.), cacti, and a variety of other thorny shrubs overtop the grasses.

The increase in shrubs has been ascribed to several causes. These have included overgrazing, dissemination of the seeds by grazing animals, and fire control. There seems to be little doubt that more than one factor has been responsible in most instances. The essential ces- sation of grassland fires, however, and those factors related to this change, appear to have had more to do with the increase in brush than any others.

Over rather extensive areas the grasses originally dominant have largely disappeared. In others, there is a fairly good understory of many of the same grasses that were common when the country was first occupied by white men. Although there is a wide variety of grasses within the desert grassland, only a few are sufficiently abundant to be classed as association dominants. Shantz and Zon (1924) subdivides the desert grassland on a basis of dominant grasses into four communities: black grama (Bouteloua eriopoda [Torr.] Torr.), crowfoot (Rothrock) grama (B. rothrockii Vasey), curly mesquite (Hilaria belangeri [Steud.] Nash) and tobosa grass (Pleuraphis mutica Buckley). It would seem that a fifth, blue grama (Bouteloua gracilis [Willd. ex Kunth] Lag. ex Griffiths), should have been listed also. Although there have been extensive changes in the floristic composition of these communities in the 28 years that have elapsed since this classification was made, a similar breakdown would be valid if made today. In general, the black grama association is best developed in New Mexico and Texas, the Rothrock grama and curly mesquite in Arizona, the tobosa grass and the blue grama throughout the Southwest. In Arizona, the Rothrock grama community seems to have changed more down through the years than any of the others. Most of the areas at one time dominated by Rothrock grama have been taken over to a large extent by shrubs. Chief 


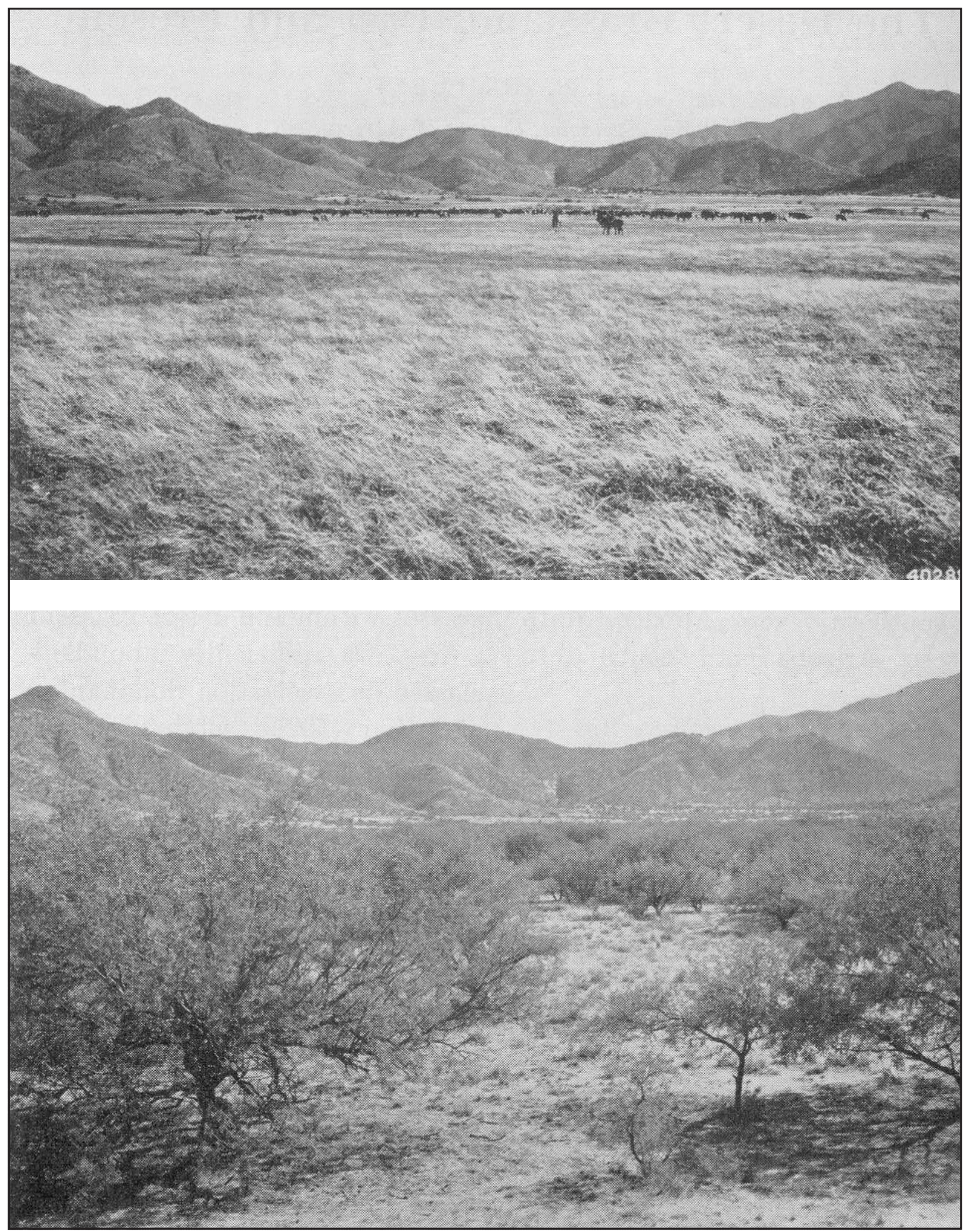

Figure 1. Upper photo: area on Santa Rita Experimental Range in 1903 (US Bureau Plant Industry photo). Contrast with photograph below showing same area in 1947. Lower photo: same area as shown above, taken in 1947 after 45 years of fire control (US Forest Service photo). 
among these are burroweed, snakeweed and mesquite. Where shrub invasion has been less intensive, annual grasses are dominant today where Rothrock grama was a few years ago

Rothrock grama should not be classed as an association dominant. Although abundant on many southern Arizona ranges, this grass seems to represent a successional stage as the ranges have deteriorated or improved. In part because of its ability to set abundant seed readily, and in part because of its short life, Rothrock grama responds rapidly to favorable moisture conditions. In this respect it resembles the annual grasses with which it is usually associated. Most black grama communities support a greater variety of other grasses and shrubs than either the curly mesquite or tobosa associations. This may be because black grama has a wider tolerance, both as to soil and moisture, than curly mesquite or tobosa. Curly mesquite shows a preference for heavy clay soils on sloping, rocky sites; tobosa for poorly drained swales that may be flooded during the rainy season.

\section{DESERT GRASSLAND, A SUBCLIMAX}

Although the desert grassland is commonly classed as a grassland climax, there is considerable evidence that the true climax here is low-growing trees and brush with a grass-halfshrub understory. Grasses were dominant throughout much of this region at the time of the first white settlement. Much, if not all, of the formation appears to have been held for an indefinite period as a grassland subclimax prior to white settlement with its concomitant domestic livestock grazing and fire control. This theory was proposed by Griffiths (1910) for southern Arizona grasslands that were being invaded by mesquite. He stated that had it not been for repeated fires, the slopes between the desert scrub and the mountain would have been covered by shrubs and trees.

This conclusion was substantiated by Brown (1950) in a study of plant succession and shrub invasion on the same southern Arizona range studied by Griffiths. Brown's analysis showed that even though mesquite increased less under 18 years of protection from grazing than on the open range, it increased 30 percent during this same period even on range protected from both domestic livestock and rabbits. Although there was a good stand of grasses within the protected areas this did not prevent or even appreciably curtail continued mesquite invasion.

In a somewhat similar study on an adjacent area, Glendening (1952) noted a comparable increase in mesquite. During the 17-year period from 1932 to 1949, the number of mesquites per hectare increased from 208 to 474 (129 percent) under total protection; from 161 to 361 (125 percent) under cattle exclusion; and from 146 to 301 (107 percent) on the open range. It is of particular interest to note that the number of trees and the rate of increases were both greater on protected range than on range open to grazing.

These studies by Brown and by Glendening indicate that encouragement of grass growth through protection from grazing is quite ineffective in preventing mesquite establishment. Observations on other long-established exclosures on the Santa Rita Experimental Range point to the same conclusion, not only with regard to mesquite, but also to cacti, burroweed and other shrubs. Although several of these exclosures are well grassed this has not been effective in preventing the establishment of brush.

These observations are in agreement with conclusions reached by South African and other workers. Phillips (1935) indicates that fire in the Great Central Plateau Region of Tanganyika prevented establishment of the shrub climax. He says:

Study of the vegetation of this great region shows that fire has played an important part in the development of the communities; apparently the ulti- 
mate expression is the Deciduous Scrub, but the stages leading thereto are inhibited in development by fire... In Africa, Busse, Jaeger, Obst, Bews, Henkel, Galpin, and Phillips among others, have been impressed with the influence of fire in retarding development toward a climax. The keeping out of fires, for example, by conscious protection, or by unintentional means, such as heavy grazing by stock, resulting in so poor a grass cover that fires are impossible, has certainly resulted in the development of woody scrub of various kinds, in South Africa and in East Africa; ...

\section{OBSERVATIONS OF EARLY WORKERS}

Observations and conclusions of early workers are of particular value in that these workers were closer to the times when the changes they recorded were taking place than we are today. They were also in a position to see the changes still active, changes that have been completed for the most part today.

Where extensive grasslands lie adjacent to trees or shrubs the tendency for grass fires to restrict the spread of the woody species appears originally to have been quite general. Gleason (1913) concluded on the basis of several years' field observation that the spread of the eastern deciduous forest westward had originally been prevented by prairie fires. He questioned whether mature trees were often killed outright by a single fire but ascribed the restricting effect largely to seedling destruction.

In southwestern United States also, early writers quite generally indicate that brush and woodland species were originally kept in check by recurrent fires. Smith (1899) observed that shrubby species that had formerly been kept in check by fires set by the Indians were invading southern Texas. Quoting Smith:
In this manner the encroachment of thorny shrubs, cactus, and mesquite was prevented, and each grew only where protected in the valleys along the streams or in scattered clumps at rare intervals in the open.

A few years later Cook (1908) also writing about southern Texas, commented:

Before the prairies were grazed the luxuriant growths of grass could accumulate for several years until conditions were favorable for accidental fires to spread. With these large supplies of fuel the fires, which swept over these prairies, were very besoms of destruction not only for man and animals but for all shrubs and trees which might have ventured out among the grass, and even for any trees or forests against which the burning wind might blow.

Cook continues with the observation that trees grow "in all situations which afford protection against fires" and that the woody vegetation spreads naturally as soon as the fires cease.

Bray (1904a, 1904b) and Foster (1917) discuss the spread of woody species in central Texas. Both cite the original prevalence of fires as the principal factor that prevented the spread of shrubs and trees. In their discussion they state that as widespread fires became a thing of the past, heavy grazing reduced the grass density and this depletion of the cover hastened the change initiated by and caused largely by control of fires. Other early workers, writing at about the same time as Cook, ascribed the increase of brush in southern Arizona to control of fires. Griffiths (1910) working on the Santa Rita Range Reserve near Tucson, Arizona, wrote: 
The probability is that neither protection nor heavy grazing has much to do with the increase of shrubs here, but that it is primarily the direct result of the prevention of fires... the grassy foothills, ... produce sufficient vegetation to burn readily, at least every other year, at the present time. Previously, before the country was stocked, it probably produced more grass than it does now and was frequently burned over, the fire extending down as far as vegetation would permit.

Wooton (1915), commenting on a prediction made by Griffiths a few years earlier that the mesquites on the Santa Rita Range Reserve would increase in size and number, noted that this prediction was already coming true. He observed:

The only retardation they have received has been from the occasional fires, some of which have been severe enough to kill plants 10 to 12 feet $[3 \mathrm{~m}$ to $4 \mathrm{~m}$ ] high, though usually only the smaller bushes are killed back to the ground.

Thornber (1910), during this same early period stated that several of the more common desert shrubs were killed by burning. His observations in part follow:

Not only was the dried annual growth burned on the open range, but such shrubs and trees as creosote bush or greasewood, rayless goldenrod, Mormon tea, bush hackberry or garanbullo (Celtis pallida) mesquite, and palo verde were killed. That such fires burning over the mesas and foothills have not been uncommon in times past may be judged by the fact that in many places abundant remains of charred stumps of at least ten years duration are frequently met with.
Three years before this, Thornber (1907) had reported on the use of fire as an economical means of killing a number of desert shrubs or half shrubs. His report stated:

All the (rayless goldenrod) plants in the area burned over, even those only partly charred, were killed outright, including such other shrubs as the catclaw, creosote bush, Brigham's tea, mesquite and Zizyphus.

Not all investigators are in agreement on the role that fire may once have played in shrub control in the Southwest. Young, Anderwald and McCully (1948) conclude that since repeated burnings do not seem to kill all the underground basal buds on mesquite "for this reason it seems doubtful that the prairie fires of the old days were actually agents in preventing the spread of the mesquite."

Allred (1948) also felt that fires had been of little or no importance in maintaining the extensive Texas grasslands on areas now largely occupied by mesquite and other shrubs.

\section{FIRE SCAR RECORDS}

Forest fires leave a fire-scar record that may be interpreted chronologically; grass fires leave few records. Weaver (1951) analyzed fire scars from log cross sections obtained at five different locations in northern Arizona. This analysis indicated that fires had occurred at frequent intervals on all the sites over the entire life span of the trees studied. The earliest fires of record dated back to 1708 A.D.; the most recent occurred in 1943. The average interval between fires on individual trees ranged from 4.8 years to 11.9 years. The average interval for all trees was 7.3 years. With evidence of this sort available on timbered ranges adjoining grasslands there would seem to be no reasonable doubt that the grasslands also were swept periodically by fires.

Many southern Arizona grasslands are crossed by drainages bordered by old mesquite 
or other trees. A cursory examination was made in 1952 along five of these drainages on the Santa Rita Experimental Range to determine whether the trees bore any evidence of old fire scars.

Thirty-two trees were examined; seventeen $30 \mathrm{~cm}$ or less in diameter, fifteen from $30 \mathrm{~cm}$ to $76 \mathrm{~cm}$. Only one with a diameter measurement of $30 \mathrm{~cm}$ or less bore any scars that showed signs of fire. Sixty-nine percent of those $36 \mathrm{~cm}$ or larger, on the other hand, bore unmistakable fire scars. Even in this size class the larger trees had a greater tendency to be scarred than the smaller ones.

Although it is many years since any fires have swept across this area or since there was enough grass on much of it to carry a fire, these numerous old scars are unmistakable evidence that at one time they did occur.

\section{SUMMARY}

A study of historical and vegetational data points to the conclusion that the desert grassland of southwestern United States and northern Mexico is not a true climax. Rather, it is a subclimax maintained by fire. Today, with fires largely a thing of the past, the true climax of low trees, brush, and cacti, with an understory of grasses and low-growing shrubs is developing extensively on areas that were once grassed.

Reprinted, with minor revisions, with permission from the Journal of Range Management, Vol. 6, No. 3 (May 1953), pp. 159-164. Published by Allen Press and the Society for Range Management.

\section{LITERATURE CITED}

Allred, B.W. 1948. Distribution and control of several woody plants in the Western Gulf Region. US Soil Conservation Service, Ft. Worth, Texas, USA. (Lithographed).

Bray, W.L. 1904a. Forest resources of Texas. USDA Forestry Bulletin 47. Washington, D.C., USA. doi: 10.5962/bhl.title.66391

Bray, W.L. 1904b. The timber of the Edwards Plateau of Texas. USDA Bureau of Forestry Bulletin 49. Washington, D.C., USA.

Brown, A.L. 1950. Shrub invasion of southern Arizona desert grassland. Journal of Range Management. 3: 172-177. doi: 10.2307/3894118

Cook, O.F. 1908. Change of vegetation in the south Texas prairies. USDA Bureau of Plant Industry Circular 14. Washington, D.C., USA. doi: 10.5962/bhl.title.67871

Foster, J.H. 1917. The spread of timbered areas in central Texas. Journal of Forestry 15: 442445.

Gleason, H.A. 1913. The relation of forest distribution and prairie fires in the Middle West. Torreya $13: 173-181$.

Glendening, G.E. 1952. Some quantitative data on the increase of mesquite and cactus on a desert grassland range in southern Arizona. Ecology 33: 319-328. doi: 10.2307/1932827

Griffiths, D. 1910. A protected stockrange in Arizona. USDA Bureau of Plant Industry Bulletin 177. Washington, D.C., USA.

Phillips, J. 1935. Succession, development, the climax, and the complex organism: an analysis of concepts. Part II. Development and the climax. Journal of Ecology 23: 210-246. doi: $10.2307 / 2256152$

Shantz, H.L., and R. Zon. 1924. Atlas of American agriculture. Part I. The physical basis of agriculture. USDA Bureau of Agricultural Economics Advance Sheets-6. Map. Washington, D.C., USA. 
Smith, G. 1899. Grazing problems in the Southwest and how to meet them. USDA Division of Agrostology Bulletin 16. Washington, D.C., USA.

Thornber, J.J. 1907. Destruction of range weeds. Page 228 in: University of Arizona Agricultural Experiment Station 18th Annual Report. Tucson, Arizona, USA.

Thorber, J.J. 1910. The grazing ranges of Arizona. Pages 246-369 in: University of Arizona Agricultural Experiment Station. Bulletin 65. Tucson, Arizona, USA.

Weaver, H. 1951. Fire as an ecological factor in the southwestern ponderosa pine forest. Journal of Forestry 49: 93-98.

Weaver, J.E., and F.E. Clements. 1929. Plant ecology. McGraw-Hill, New York, New York, USA.

Wooton, E.O. 1916. Carrying capacity of grazing ranges in southern Arizona. USDA Bulletin 367. Washington, D.C., USA.

Young, V.A., F.R. Anderwald, and W.G. McCully. 1948. Brush problems on Texas ranges. Texas Agricultural Experiment Station Miscellaneous Publication 21. College Station, Texas, USA. 